\title{
The Study on Possible Applications of Lightweight Concrete Based on Waste Aggregate in Terms of Compressive Strength and Thermal Insulation Properties
}

\author{
Anna Smoczkiewicz-Wojciechowska*, Marta Sybis, Jacek Mądrawski, \\ Wojciech Kostrzewski
}

Department of Civil Engineering and Geoengineering, Faculty of Environmental and Mechanical Engineering, Poznań University of Life Sciences, Poland

Received: 23 January 2021

Accepted: 28 April 2021

\begin{abstract}
The leading theme of the paper was to study, how the use of lightweight concrete based on waste aggregates, characterized by significant mechanical strength and increased thermal insulation, affects the properties of building partitions and contributes to possible economic savings, so as to properly design and select materials required for the construction process.

The work presents the composition of lightweight concrete samples made of waste lightweight aggregates as well as their physical and mechanical properties. It includes calculations concerning floor loading and heat transfer coefficient of building partitions made of the presented lightweight concretes. Calculations provided the basis for assessing the impact of particular parameters on compressive strength and thermal insulation of walls and floors. The paper additionally describes concretes made of waste aggregates in the form of lytag (Pollytag) and slag. Based on the research, it was found that concrete containing Pollytag had the lowest density value and thermal conductivity coefficient. These parameters translated into reduction in the weight of the slab in question by more than $40 \%$ and allowed to save $25 \%$ of steel compared to an analogous plain concrete slab. The decrease in heat conductivity coefficient did not result in a significant increase in thermal insulation of building partitions.
\end{abstract}

Keywords: lightweight concrete, compressive strength, thermal conductivity

*e-mail: anna.smoczkiewicz-wojciechowska@up.poznan.pl 


\section{Introduction}

Modern construction materials, including concrete, should be differentiated with high mechanical strength, good thermal and acoustic properties, as well as proenvironmental characteristics. Waste aggregate can be used as an alternative material to produce lightweight concrete with low environmental impact $[1,2]$. In order to meet the existing numerous requirements, the manufacturers of building materials have been constantly modifying the composition of concrete mix for obtaining the best possible parameters [3]. The question remains open whether such improvements might be converted into real benefits.

On the basis of the data collected weekly from commercial companies - the members of the Polish Union of Steel Distributors, there were monitored the average wholesale prices of reinforcing steel. The above changing data helped to determine an upward price trend of reinforcing bars. Therefore, it is worth considering whether the use of lightweight concrete can result in savings on reinforcement.

The situation is similar with the continuing growth in energy consumption. Currently, the fact has been drawing great attention from governments, industry and academics. The mechanical properties of lightweight concrete are satisfactory, as evidenced by numerous studies. Considering energy savings, it is also recommended to verify the thermal insulation parameters of materials [4-7].

The thermal insulation parameters of concrete in the construction industry have been undertaken as a research topic by many scientists, what finds confirmation in large amount of scientific literature: [8], [9-19]. Authors in their works emphasise the importance of proper insulation of construction materials and analyse the correlation between density, compressive strength and thermal conductivity. The popular trend of research is the use of various waste aggregates such as: fly ash, rubber aggregate, blast furnace slag, rice hush ash, palm oil fuel, pumice powder, polyethylene, volcanic ash, glass powder, paper sludge ash. There are still valid attempts to use less known light aggregates such as lytag [20, 21]. The issue of using waste aggregate obtained from coconut oil production was discussed by Alengaram [11], who compared the thermal insulation properties of the obtained concrete with traditional materials such as bricks or plain concrete. Lightweight aggregates in the form of pumice powder, expanded perlite or waste rubber aggregates were the subject of research described by Oktay [15]. The results presented in Alyousef [22] paper showed that the incorporation of sand obtained from marble waste and perlite aggregate notably improved the mechanical properties and the thermal insulation of lightweight concrete.

A significant improvement in thermal insulation has been observed depending on types and percentages of waste aggregate used in concrete.
According to the latest trends in concrete technology, lightweight concrete, which accordingly to PN-EN 206+A1:2016-12 [23] has density below $2000 \mathrm{~kg} / \mathrm{m}^{3}$ and is included in strength classes between LC8/9 and LC80/88, is particularly desirable. The classes from LC50/55 to LC80/88 are lightweight concrete classes of high compressive strength characteristics. Owing to the use of lightweight aggregate, such concretes allow for producing lighter structural elements with, in consequence, reduced static loads and improved loadbearing capacity. Unfortunately, lower density often leads to lower compressive strength of the material and results in changes in its insulation properties. The porous structure of lightweight aggregate is responsible for differences in mechanical and thermal performance of lightweight concrete compared to normal weight concrete [24, 25].

The paper presents the comparison of compressive strength characteristics of concrete made of waste aggregates, such as slag and Pollytag, and includes a comparative analysis of the calculated floor slab made of the designed materials and the standard concrete slab of similar compressive strength parameters. It also calculates how the use of lightweight concrete with reduced thermal conductivity affects insulation properties of building partitions.

\section{Material and Methods}

\section{Materials}

\section{Cement}

Cement used for the tests was certified as CEM III 52.5. It was produced by Górażdże Cement S.A. Heidelbergcement Group, Poland. This is a new product offered by the cement plant designed specifically for buildings exposed to significant loads and chemical corrosion risks.

\section{Pollytag}

For the purpose of the study Lytag (Pollytag) was used - a light type of aggregate manufactured by granulation and sintering of fly ash at temperature between 1000 and $1350^{\circ} \mathrm{C}$. The aggregate is characterised by its lightweight, high refractoriness and particularly high compressive strength. The material applied in the study was manufactured by POLLYTAG, Gdańsk Polska. The grain diameter ranged from 4-8mm to $8-14 \mathrm{~mm}$, with bulk density $770 \mathrm{~kg} / \mathrm{m}^{3}$. 10 -minute absorbability was $23.6 \%$ and the value for 24 -hour absorbability $-27.9 \%$, respectively. The aggregate is shown in Fig. 1a).

\section{Boiler Slag}

The presented concrete mixes used boiler slag as an additional waste aggregate, which is a by-product of 
a)

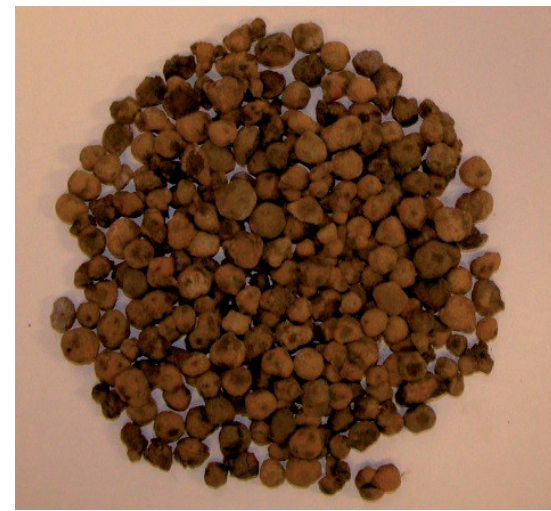

b)

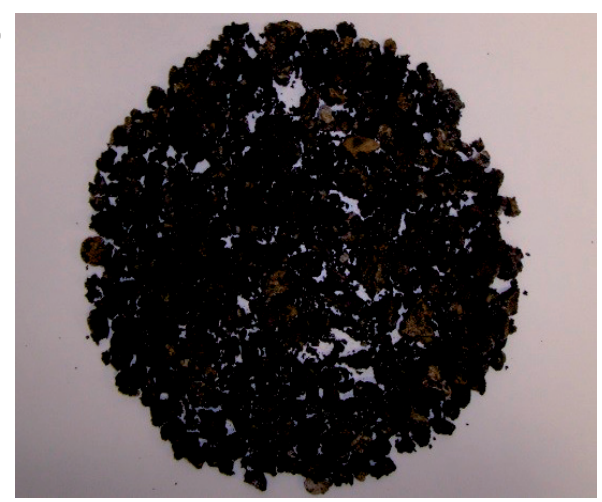

Fig. 1. Photographs of waste aggregates used in the study: a) pollytag, b) boiler slag.

hard coal incineration in grate furnaces. The material was received from an electrothermal power plant located in the city of Poznan in Poland. Its bulk density equalled $885 \mathrm{~kg} / \mathrm{m}^{3}, 10$-minute absorbability was $19.9 \%$, whereas 24 -hour absorbability came to $22.4 \%$. The maximum grain diameter was $16 \mathrm{~mm}$. The aggregate is shown in Fig. 1b).

\section{Omega-Spheres}

Lightweight aggregate in the form of hollow ceramic micro-spheres characterised by good mechanical and thermal properties. The material used for the purpose of the study was received from Omega Minerals, Germany. The concrete mix formulas used the aggregate with the grain diameter $0.5 \mathrm{~mm}$ and bulk density $0.8 \mathrm{~g} / \mathrm{cm}^{3}$.

\section{Micro-Silica}

Micro-silica is a type of waste captured in the ferrosilicon smelting process. The material used for the study was received from Huta Łaziska, in Silesia. Micro-silica exhibited pozzolanic properties. The diameter of micro-silica grain was approx. $0.5 \mu \mathrm{m}$, its bulk density equalled to $2.18 \mathrm{~g} / \mathrm{cm}^{3}$.

\section{Ground Slag}

Ground slag was received by grinding boiler slag (described in the study). The process was carried out in a ball mill to the cement fineness $3600 \mathrm{~cm}^{2} / \mathrm{g}$.

\section{Chemical Admixtures}

In order to obtain concretes of the highest possible compressive strength parameters, the $4^{\text {th }}$ generation superplasticizer of high-performance (SP 10 designation), based on polycarboxyl ethers was used in the study. The material was received from Schomburg, Germany.

\section{Water}

Water from the local water supply was used for the study.

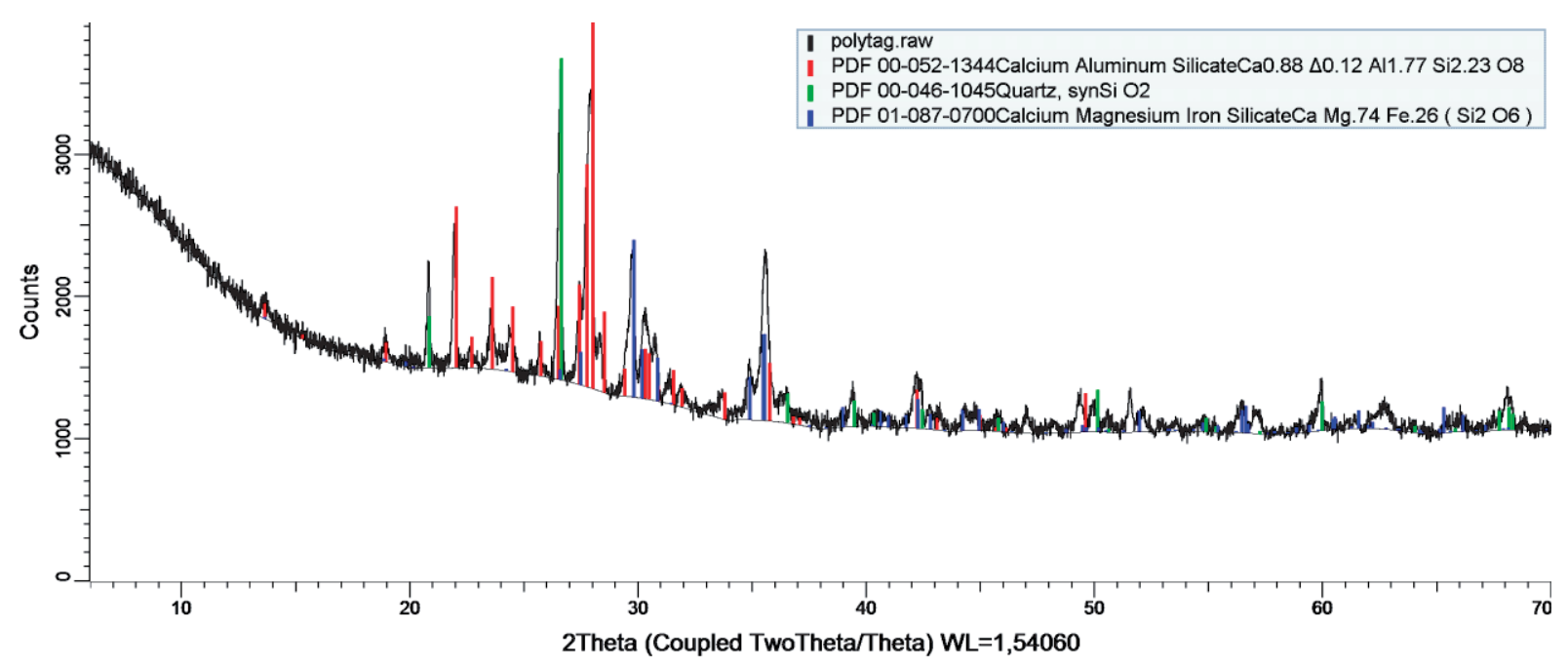

Fig. 2. Elemental XRD analysis for pollytag. 


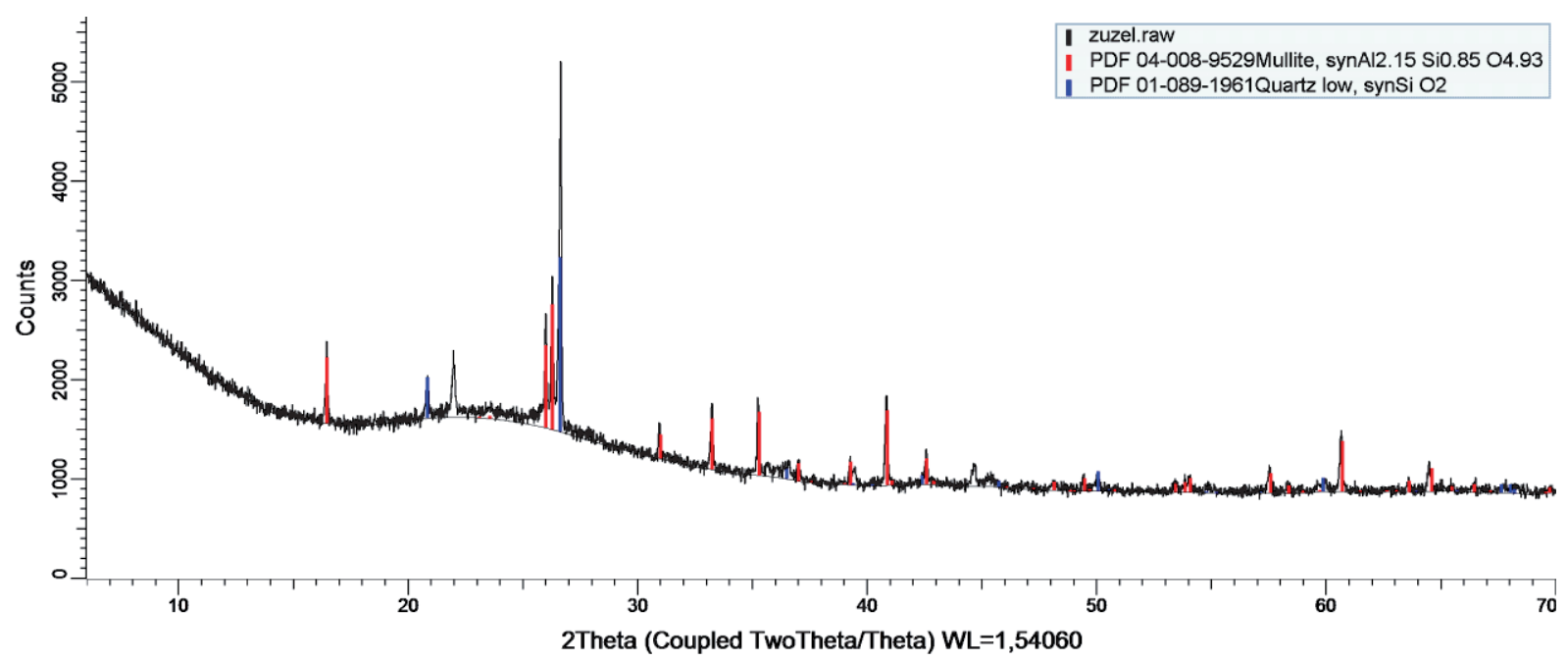

Fig. 3. Elemental XRD analysis for boiler slag.

\section{Elemental XRD Analysis}

To check the elemental composition of the additives used (Pollytag and boiler slag), a powder diffractometer test (BRUKER D8 Advance) was performed. The research was carried out at The Laboratory of Unique Chemical Equipment at Adam Mickiewicz University, Poznan, Poland. The test results are shown in Figs 2 and 3.

Elemental XRD analysis for pollytag showed the presence of Calcium Aluminum Silicate, Quartz and Calcium Magnesium Iron Silicate (Fig. 2). In the case of the boiler slag, the presence of Mullite (A12.15 Si0.85 O4.93) and Quartz was detected.

\section{Compositions of Concrete Mixes and Their Properties}

The above presented components were used to prepare concrete mixes. Their detailed compositions

Table 1. Composition of concrete mixes.

\begin{tabular}{|c|c|c|}
\hline Concrete mix composition & $\begin{array}{c}\text { P - Pollytag } \\
{\left[\mathrm{kg} / \mathrm{m}^{3}\right]}\end{array}$ & $\begin{array}{c}\text { Z-slag } \\
{\left[\mathrm{kg} / \mathrm{m}^{3}\right]}\end{array}$ \\
\hline Cement & 380 & 320 \\
\hline Pollytag $(0 \div 2) \mathrm{mm}$ & 213 & \\
\hline Pollytag $(2 \div 4) \mathrm{mm}$ & 67 & \\
\hline Pollytag $(4 \div 14) \mathrm{mm}$ & 605 & 409 \\
\hline Slag $(0 \div 4) \mathrm{mm}$ & & 607 \\
\hline Slag $(4 \div 8) \mathrm{mm}$ & 85 & 68 \\
\hline Omega spheres & 3,8 & 5.3 \\
\hline Plasticizer & 155 & 258 \\
\hline Water & 62 & 60 \\
\hline Micro-silica & & \\
\hline
\end{tabular}

are included in the table (Table 1). Concrete mixes with Pollytag are indicated with $\mathrm{P}$, and concrete mixes with slag $-Z$, respectively.

The results of laboratory tests on density, heat transfer coefficient and compressive strength are summarized in the table (Table 2). The properties of concrete were tested in laboratory conditions. The compressive strength of samples was examined using a Walter+Baiag 107/3000A/J press. The heat transfer coefficient was determined with the use of Isomet, a multifunctional instrument for measuring thermal conductivity.

\section{Structural Calculations Concerning the Floor Slab}

The use of lightweight concrete as a structural material can be associated with real savings in the construction process due to the possibility of reducing the self-weight of a structure while retaining high compressive strength parameters for concrete and significant cost-effectiveness for reinforcing steel.

In order to verify of this assumption, three reinforced concrete slabs made of three different concrete mixtures were designed for the study including:

- Pollytag (hereinafter referred to as lightweight concrete P),

- slag (hereinafter referred to as lightweight concrete Z),

Table 2. Summary of laboratory test results.

\begin{tabular}{|c|c|c|}
\hline \multirow{2}{*}{$\begin{array}{c}\text { The scope } \\
\text { of laboratory tests }\end{array}$} & \multicolumn{2}{|c|}{ Summary of results } \\
\cline { 2 - 3 } & P -pollytag & Z-slag \\
\hline Average density of the sample $\left[\mathrm{kg} / \mathrm{m}^{3}\right]$ & 1400 & 1700 \\
\hline Average value $\lambda[\mathrm{W} / \mathrm{mK}]$ & 0.38 & 0.63 \\
\hline $\begin{array}{c}\text { Average compressive strength of the } \\
\text { reference samples [MPa] }\end{array}$ & 36.4 & 45.6 \\
\hline
\end{tabular}


- natural aggregate (hereinafter referred to as plain concrete).

The tested concrete samples were characterised by different density, therefore, the slabs - including

Table 3. Characteristic self-weight values of slabs.

\begin{tabular}{|c|c|}
\hline Type of the slab & Characteristic value $\left[\mathrm{kN} / \mathrm{m}^{2}\right]$ \\
\hline Plain concrete & 4.00 \\
\hline Lightweight concrete $\mathrm{Z}$ & 2.77 \\
\hline Lightweight concrete $\mathrm{P}$ & 2.29 \\
\hline
\end{tabular}

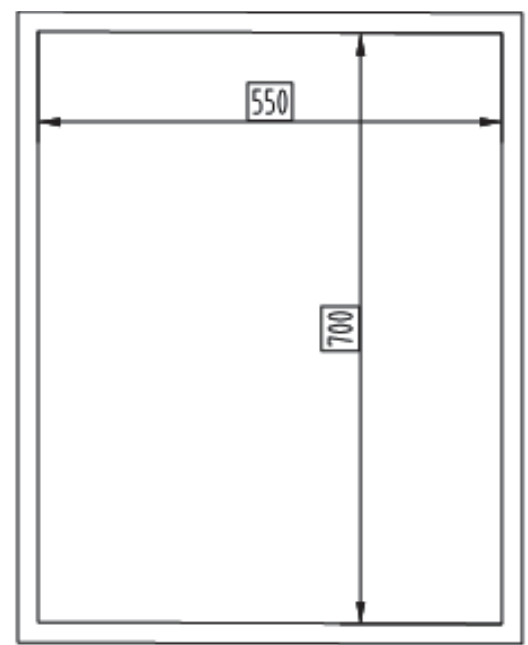

Fig. 4. Dimensions of slabs.

Table 4. Basic parameters of the designed slabs.

\begin{tabular}{|c|c|}
\hline Lx & $5.5 \mathrm{~m}$ \\
\hline Ly & $7.0 \mathrm{~m}$ \\
\hline Concrete class & $\mathrm{C} 30 / 37$ \\
\hline Steel A-IIIN & $\mathrm{f}_{\mathrm{yk}}=500 \mathrm{MPa}$ \\
\hline Exposure class & $\mathrm{XC} 1$ \\
\hline Structure class & $\mathrm{S} 4$ \\
\hline Height of the slab & $16 \mathrm{~cm}$ \\
\hline $\mathrm{f}_{\mathrm{ctm}}$ & $2.9 \mathrm{MPa}$ \\
\hline
\end{tabular}

reinforcement - were varied in terms of weight. The values are presented in the table (Table 3 ).

The calculations were prepared for $16 \mathrm{~cm}$ thick slabs with dimensions $5.5 \mathrm{~m}$ (x) x $7.0 \mathrm{~m}$ (y) - Fig. 4 . Following the compressive strength laboratory tests on concrete cubic blocks with sides equal to $15 \mathrm{~cm}$, there was indicated the class of concrete as C30/37. For the calculations it was assumed that the slabs were reinforced with RB 500W steel bars of yield strength $\mathrm{f}_{\mathrm{yk}}=500 \mathrm{MPa}$. The samples included ribbed slabs with diameters $\varnothing=6 \mathrm{~mm}$ (along the longer side - direction y) and $\varnothing=8 \mathrm{~mm}$ (along the shorter side - direction $\mathrm{x}$ ).

The authors assumed the characteristic value of live load, including the loading of partition walls, as equal to $3.25 \mathrm{kN} / \mathrm{m}^{2}$. The layout of the slab was adopted as a structure freely supported on all its edges. Bending moments were calculated using the appropriate tables [27]. Reinforcement was designed according to PNEN 1992-1-1:2008+A1:2015-03 [28]. The adopted parameters for the design of reinforced concrete slabs are shown in the table (Table 4)

\section{Results and Discussion}

\section{Designed Slabs}

For the assumed data (presented in section 2), the maximum bending moments were determined and the reinforcement cross-sections was calculated (Table 5).

Then, drawings of the bottom and top reinforcement of the plates were made and compiled list of reinforcing steel was made. Fig. 5 shows the reinforcement of the lightweight concrete $\mathrm{Z}$ slab.

By analyzing the results shown in Table 6 , it may be concluded that the use of concrete based on Pollytag can save almost $25 \%$ of reinforcing steel. The use of light concrete with Pollytag is also associated with a much lower weight of the whole floor slab (over 40\%), which will contribute to further savings in the construction process (Table 7).

Despite the low density of light aggregate concretes (up to $2000 \mathrm{~kg} / \mathrm{m}^{3}$ ), they may demonstrate relatively high compressive strength values, depending on the type of aggregate used. Calculations on the structural floor slab confirmed that lightweight concrete had the strongest impact on the demonstrated values. The total

Table 5. Maximum bending moments and assumed reinforcement for the designed reinforced concrete slabs.

\begin{tabular}{|c|c|c|c|}
\hline & Plain concrete & Lightweight concrete Z & Lightweight concrete P \\
\hline Mx,max & $22.282 \mathrm{kNm}$ & $19.077 \mathrm{kNm}$ & $17.833 \mathrm{kNm}$ \\
\hline My,max & $12.756 \mathrm{kNm}$ & $10.921 \mathrm{kNm}$ & $10.209 \mathrm{kNm}$ \\
\hline Reinforcement (direction x) & $\begin{array}{c}\mathrm{A}_{\text {slx }}=4.17 \mathrm{~cm}^{2} \\
\varnothing 8 \text { every } 12 \mathrm{~cm}\end{array}$ & $\begin{array}{c}\mathrm{A}_{\text {slx }}=3.57 \mathrm{~cm}^{2} \\
\varnothing 8 \text { every } 14 \mathrm{~cm}\end{array}$ & $\begin{array}{c}\mathrm{A}_{\text {slx }}=3.33 \mathrm{~cm}^{2} \\
\varnothing 8 \text { every } 15 \mathrm{~cm}^{2}\end{array}$ \\
\hline Reinforcement (direction y) & $\begin{array}{c}\mathrm{A}_{\text {sly }}=2.57 \mathrm{~cm}^{2} \\
\varnothing 6 \text { every } 11 \mathrm{~cm}\end{array}$ & $\begin{array}{c}\mathrm{A}_{\text {sly }}=2.17 \mathrm{~cm}^{2} \\
\varnothing 6 \text { every } 13 \mathrm{~cm}\end{array}$ & $\begin{array}{c}\text { Asly }=2.02 \mathrm{~cm}^{2} \\
\varnothing 6 \text { every } 14 \mathrm{~cm}^{2}\end{array}$ \\
\hline
\end{tabular}



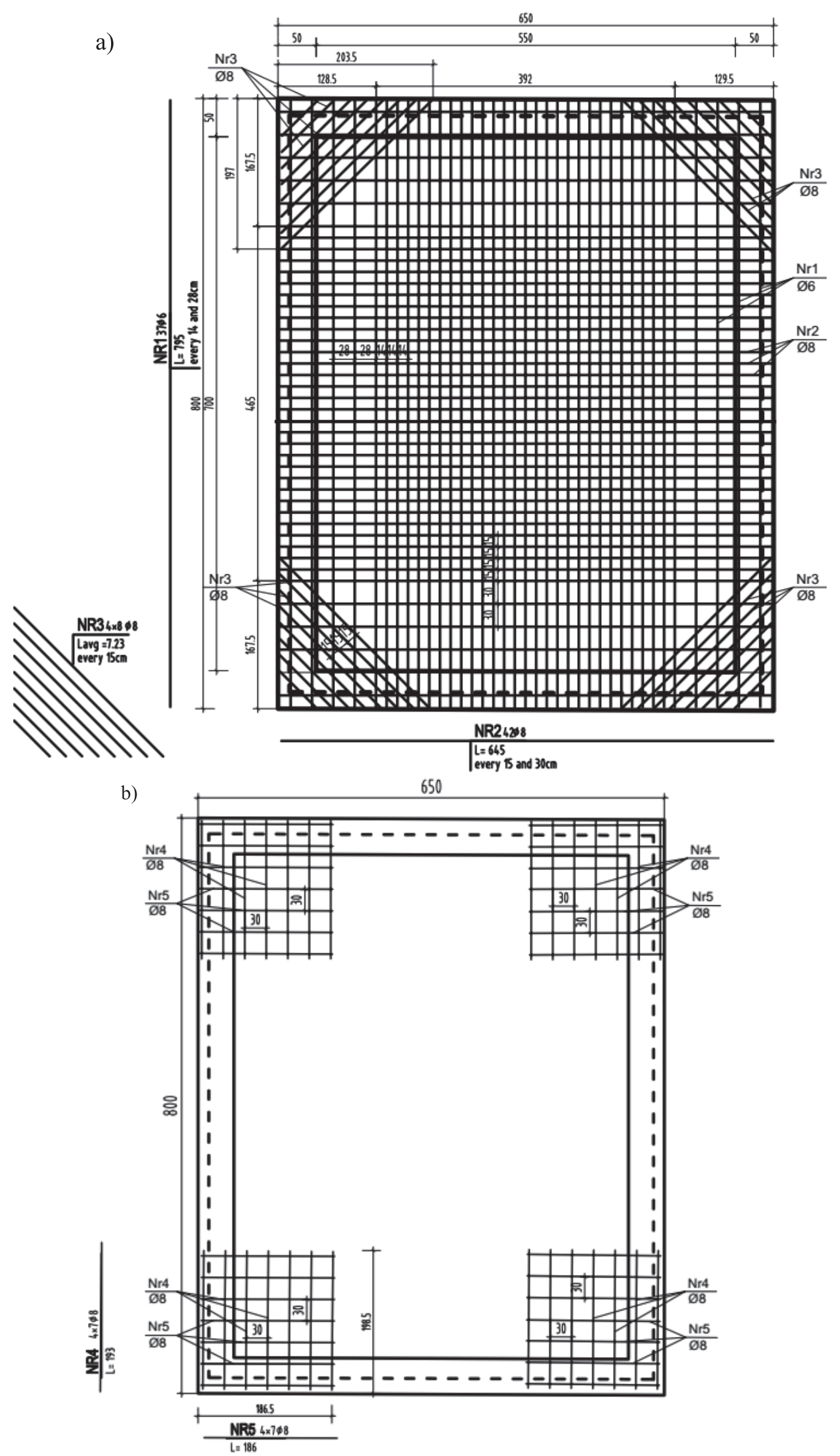

Fig. 5. Drawing of the reinforcement of the lightweight concrete $Z$ slab, a) bottom reinforcement, b) top reinforcement. 
Table 6. Total weight of reinforcement of particular slabs.

\begin{tabular}{|c|c|}
\hline Type of the slab & $\begin{array}{c}\text { Total weight of reinforcement } \\
{[\mathrm{kg}]}\end{array}$ \\
\hline Plain concrete & 291.08 \\
\hline Lightweight concrete Z & 247.69 \\
\hline Lightweight concrete P & 235.84 \\
\hline
\end{tabular}

weight of the slab including reinforcing was reduced by $40 \%$, and the weight of reinforcing steel was reduced by $25 \%$.

Thermal Insulation Calculations Related to Building Partitions Made of the Developed

Lightweight Concretes in Comparison to Plain Concrete

The concrete samples presented by authors were characterised not only by high compressive strength, but also by good thermal insulation parameters, since the coefficient $\lambda$ was $0.38 \mathrm{~W} / \mathrm{mK}$. The averaged values of thermal conductivity coefficient for subsequent series of concrete samples are presented in the table (Table 2).

The determined thermal conductivity values of lightweight concrete samples were compared with the reference data, where plain concrete with $2400 \mathrm{~kg} / \mathrm{m}^{3}$ density had the coefficient $\lambda=1.7 \mathrm{~W} / \mathrm{mK}$.

Lightweight concrete prepared in this way can improve thermal insulation parameters of walls without the necessity to make them thicker. This creates new opportunities for the use of the presented material in broadly understood construction. The table (Table 8) shows heat transfer coefficients $\mathrm{U}\left[\mathrm{W} / \mathrm{m}^{2} \mathrm{~K}\right]$ for external partitions made of solid concrete elements differing in density and thermal conductivity coefficients. As of January 1, 2021 [29], the heat transfer coefficient for an external wall at $\mathrm{ti} \geq 16^{\circ} \mathrm{C}$ cannot exceed $0.20\left(\mathrm{~W} / \mathrm{m}^{2} \cdot \mathrm{K}\right)$ (maximum value). Calculations were made for full partitions, except for the effect of thermal bridges.

The search for building materials with the lowest heat transfer coefficient aims to improve thermal insulation of partitions without thickening them. Unfortunately, the reduction in thermal conductivity coefficient, lambda $(\lambda)$, does not result in a significant change in heat transfer coefficient and, as a result, in reduction in thickness of an insulation layer. The lack of significant correlation should be borne in mind while selecting appropriate construction materials. Material characterised by higher heat transfer coefficient will not always contribute to savings on insulation, particularly when polystyrene boards are considered, which are sold in standard thickness: $5 \mathrm{~cm}, 8 \mathrm{~cm}, 10 \mathrm{~cm}, 12 \mathrm{~cm}$, $15 \mathrm{~cm}$, and similar. The situation is more favorable for insulation boards available in a greater range of thickness between $1 \div 30 \mathrm{~cm}$ with a difference in dimensions every $10 \mathrm{~mm}$. Depending on the individual needs of customers, the required thickness of an insulation layer can be selected adequately.

Many manufacturers of building materials encourage customers to purchase their brand by highlighting the importance of lower thermal conductivity coefficient compared to other products available on the market. However, they do not provide detailed information on what amount of savings on insulating materials can actually be made. On the basis of results included in Table 3 it is readily apparent that the change in thermal conductivity coefficient even from $\lambda=1.7[\mathrm{~W} / \mathrm{mK}]$ (for plain concrete) to $\lambda=0.38[\mathrm{~W} / \mathrm{mK}]$ (lightweight

Table 7. Total slab weight and percentage gain.

\begin{tabular}{|c|c|c|}
\hline Type of the slab & $\begin{array}{c}\text { Weight of the slab with reinforcement } \\
{[\mathrm{t}]}\end{array}$ & $\begin{array}{c}\text { Reduction in slab weight in relation to the reference slab } \\
{[\%]}\end{array}$ \\
\hline Plain concrete & 15.09 & - \\
\hline Lightweight concrete Z & 10.30 & 31.7 \\
\hline Lightweight concrete P & 8.84 & 41.4 \\
\hline
\end{tabular}

Table 8. Comparison of heat transfer coefficient for external partitions made of concrete with different thermal properties (according to PN-EN ISO 6946:2008 [29]).

\begin{tabular}{|c|c|c|c|c|c|}
\hline $\begin{array}{c}\text { Structural material } \\
\text { of external partition }\end{array}$ & $\begin{array}{c}\text { Density of } \\
\text { concrete }\end{array}$ & $\begin{array}{c}\text { Thickness } \\
\text { of concrete } \\
\text { partition }\end{array}$ & $\begin{array}{c}\text { Thermal } \\
\text { conductivity } \\
\text { coefficient of concrete } \lambda\end{array}$ & $\begin{array}{c}\text { Thickness of insulation } \\
\text { material (Styrofoam } \\
\lambda=0.04[\mathrm{~W} / \mathrm{mK}]\end{array}$ & $\begin{array}{c}\text { Heat transfer } \\
\text { coefficient of external } \\
\text { partition }\end{array}$ \\
\hline Units & {$\left[\mathrm{kg} / \mathrm{m}^{3}\right]$} & {$[\mathrm{m}]$} & {$[\mathrm{W} / \mathrm{mK}]$} & 0.19 & {$[\mathrm{~W}]$} \\
\hline Plain concrete & 2400 & 0.24 & 1.7 & 0.18 & 0.20 \\
\hline $\begin{array}{c}\text { Lightweight concrete } \\
\text { with slag }\end{array}$ & 1700 & 0.24 & 0.63 & 0.17 & 0.20 \\
\hline $\begin{array}{c}\text { Lightweight concrete } \\
\text { with Pollytag }\end{array}$ & 1400 & 0.24 & 0.38 & 0.20 \\
\hline
\end{tabular}


concrete based on Pollytag) allows for reducing the thickness of an insulation layer by only $2 \mathrm{~cm}$.

It should also be emphasized that obtaining very good thermal insulation of a building partition requires the elimination of as many thermal bridges as possible. To achieve it, it is necessary to use, inter alia, thin joints (called adhesive-bonded joints), counteracting the heat escape through joints between blocks. The relatively small savings in the insulation stage of works, however, should not deter customers from searching for advanced building materials with higher thermal conductivity. In accordance with the principle - even a slight improvement in building material properties can ultimately provide energy efficiency and economic benefits.

\section{Conclusions}

1. The use of lightweight concrete as a building material reduces the self-weight of slabs by $40 \%$ in comparison to plain concrete slabs, and correspondingly decreases the value of permanent loads acting on them.

2. Lightweight concretes designed on the basis of waste aggregates allow for multi-faceted savings on: reduction in reinforcement (even by $25 \%$ ), and as a consequence, in transport of materials and construction time.

3. With the existing requirements for thermal insulation of buildings, the presented concretes, despite low thermal conductivity coefficient, do not allow for complete resignation from applying insulation materials. However, improved thermal properties make it possible to slightly reduce the thickness of an insulation layer.

4. An additional advantage of the presented concretes is the use of waste aggregates for their production, which raises their ecological and economic values.

\section{Conflict of Interest}

The authors declare no conflict of interest.

\section{References}

1. ZÁLESKÁ M., PAVLÍKOWÁ M., JANKOWSKÝ O., POKORNÝ J., PAVLÍK Z. Lightweight concrete made with waste expanded polypropylene-based aggregate and synthetic coagulated amorphous silica. Ceramics-Silikaty 62 (3), 221, 2018

2. ATTANASIO A., LARGO A., ALVAREZ I., SONZOGNI F., BALACEANU L. Sustainable aggregates from secondary materials for innovative lightweight concrete products. Heron vol. 60 No. $1 / 2,2015$.

3. SHAHEDAN N.F., ABDULLAH M.M.B., NORSURIA M., KUSBIANTORO A., BINHUSSAIN M., ZAILAN S.N. Review on Thermal Insulation Performance in Various Type of Concrete. Cite as: AIP Conference
Proceedings $\quad 1835, \quad$ https://doi.org/10.1063/1.4981868 Published Online: 26 April 2017.

4. NARAYANAN N., RAMAMURTHY K. Structure and properties of aerated concrete: a review. Cement Concrete Composites, 22 (5) 321, 2000.

5. ZÁLESKÁ M., POKORNÝ J., PAVLÍKOWÁ M., PAVLÍK $Z$. The thermal and mechanical performance of cementbased composites with enhanced thermal insulation properties. AIP Conference Proceedings, 1866, 2017.

6. KOSTRZEWSKI W., MĄDRAWSKI J., SMOCZKIEWICZ-WOJCIECHOWSKA A. Thermal and mechanical properties of lightweight concretes based on waste aggregates. Indian Journal of Engineering and Materials Sciences 25 (2), 191-198, 04.2018.

7. ALI M.R., MASLEHUDDIN M., SHAMEEM M., BARRY M.S., Thermal resistant lightweight concrete with polyethylene beads as coarse aggregates. Construction and Building Materials, 164, 739, 2018.

8. KIM K.H, JEON S.E., KIM J.K., YANG S. An experimental study on thermal conductivity of concrete. Cement and Concrete Research, 33 (3), 363, 2003.

9. DEMIRBOĞA R. Thermal conductivity and compressive strength of concrete incorporation with mineral admixtures. Building and Environment vol. 07, 2467, 2007.

10. BENAZZOUK A., DOUZANE O., MEZREB K., LAIDOUDI B., QUÉNEUDEC M. Thermal conductivity of cement composites containing rubber waste particlesExperimental study and modeling. Construction and Building Materials, 22 (4), 573, 2008.

11. ALENGARAM U.J., AL MUHIT B.A., JUMAAT M.Z., LIU YONG JING M. A comparison of the thermal conductivity of palm shell foamed concrete with conventional materials. Materials and Design 51, 522, 2013.

12. HIRASKAR K.G., PATIL C. Used of blast furnace slag aggregate in concrete. International Journal of Scientific and Engineering Research 4 (5) 95, 05.2013.

13. HUANG X., RANADE R., ZHANG Q., NI W., LI V.C. Mechanical and thermal properties of green lightweight engineered cementitious composites. Construction and Building Materials vol. 48, 954-960, 11.2013.

14. YONG JING LIU M., ALENGARAM J.U., JUMATT Z.M., HUNG MO K. Evaluation of thermal conductivity, mechanical and transport properties of lightweight aggregate foamed geopolymer concrete. Energy and Buildings 72, 238, 2014.

15. OKTAY H., YUMRUTAŞ R., AKPOLAT A. Mechanical and thermophysical properties of lightweight aggregate concretes. Construction and Building Materials 96, 217, 2015.

16. ZHU L., DAI J., BAI G., ZHANG F., Study on thermal properties of recycled aggregate concrete and recycled concrete blocks. Construction and Building Materials, vol. 94, 30, 620, 09.2015.

17. MO K.H., BONG C.S., ALENGARAM U. J., JUMAAT M.Z., YAP S.P. Thermal conductivity, compressive and residual strength evaluation of polymer fiberreinforced high volume palm oil fuel ash blended mortar. Construction and Building Materials 130, 113, 2017.

18. MO K.H., LING T-C., ALENGARAM U.J., YAP S.P., YUEN C.W. Overview of supplementary cementitious materials usage in lightweight aggregate concrete. Construction and Building Materials 139, 403, 2017.

19. CHUNG S.Y., ELRAHMAN M.A., STEPHAN D., KAMM P.H. The influence of different concrete additions 
on the properties of lightweight concrete evaluated using experimental and numerical approaches. Construction and Building Materials, 189, 314, 2018.

20. LI. J. Research on mechanical properties of fiber reinforced lytag concrete. International Journal of Science, 4, 12.2017.

21. BEJAN G., BĂRBUȚĂ M., VIZITIU R. Ș., BURLACU A. Lightweight Concrete with Waste - Review. Procedia Manufacturing 46, 136, 2020.

22. SIWAKAMI S., KAMESHWARI B. Influence of fly ash and LYTAG light weight aggregate on concreto International. Journal of Applied Engineering Research 10 (15), 35843, 09.2015.

23. ALYOUSEF R., BENJEDDOU O., SOUSSI C., KHADIMALLAH M.A., JEDIDI M. Experimental study of new insulation lightweight concrete block floor based on perlite aggregate, natural sand, and sand obtained from marble waste. Advances in Materials Science and Engineering, 14, 2019.
24. PN-EN 206+A1:2016-12 Concrete - Requirements, properties, production and compatibility

25. CAVALLINE T.L., CASTRODALE R.W., FREEMAN C., WALL J. Impact of lightweight aggregate on concrete thermal properties. Materials Journal 114 (6), 945, 11.01.2017.

26. REAL S., BOGAS A.J., GOMES M.G., FERRER B. Thermal conductivity of structural lightweight aggregate concrete. Magazine of Concrete Research, 68 (15), 798, 2016.

27. BAREŚ R. Tables for the Analysis of Plates, Slabs and Diaphragms based on Elastic Theory, Auflage, 1969.

28. PN-EN 1992-1-1:2008+A1:2015-03 Eurocode 2 - Design of concrete structures

29. PN-EN ISO 6946:2008 Building components and building elements - Thermal resistance and heat transfer coefficient - Calculation method. 
